\title{
WORK-LIFE BALANCE AS A FACTOR OF JOB SATISFACTION IN SOCIAL CARE SERVICES IN LITHUANIA
}

\author{
Laimutė Žalimienė, Jolita Junevičienė \\ Lithuanian Social Research Centre
}

\begin{abstract}
Studies based upon surveys in different countries demonstrate that work-life balance (WLB) is one of important factors of job satisfaction (JS). The present article tries to reveal WLB as a factor of JS in social care services in Lithuania. This sector is interesting due to the fact that personal social services as a separate area of welfare, as well as the profession of social work, was established in Lithuania only after 1990 and, therefore, is little researched. The research findings showed that, if to build upon the overall evaluation approach, WLB is an important factor of JS in social care services in Lithuania. In other words, employees satisfied with WLB in their organisation are more likely to be satisfied with job in general. On the other hand, if to use the components approach, whereby WLB consists of multiple aspects that define the balance and give specific meaning to it, not all WLB factors identified in the research have been found significant for both overall assessment of WLB and JS. Therefore, the overall assessment of WLB does not provide basis to formulate recommendations for improving social policy. This requires creating a framework of WLB that is as detailed and systematic as possible, while restricted list of factors may produce incomplete WLB "picture" within the organisation. KEY WORDS: work-life balance, job satisfaction, social care, Lithuania.
\end{abstract}

\begin{abstract}
Anotacija
Ivvairiose užsienio šalyse atliekami tyrimai atskleidè, kad darbinio ir šeiminio gyvenimo pusiausvyra yra vienas svarbiausių pasitenkinimo darbu veiksnių. Šiuo straipsniu siekiama atskleisti darbinio ir šeiminio gyvenimo derinimo problemą, kaip pasitenkinimo darbu veiksnị Lietuvos socialinès globos paslaugų sektoriuje. Pastarasis sektorius įdomus tuo, kad Lietuvoje asmeninès socialinès paslaugos, kaip paskira gerovès sritis, kaip ir socialinio darbuotojo profesija, pradètos teikti tik po 1990 metų. Tad ši sritis mažai tyrinèta. Tyrimo rezultatai atskleidè, kad taikant visa apimančią prieigą (angl. overall approach) darbinio ir šeiminio gyvenimo pusiausvyra yra svarbus pasitenkinimo darbu veiksnys globos paslaugų sektoriuje Lietuvoje. Kitaip tariant, jeigu darbuotojas patenkintas darbinio ir šeiminio gyvenimo derinimu organizacijoje, jis dažniausiai bus patenkintas ir apskritai savo darbu. Kita vertus, taikant komponentų prieigą (angl. component approach), kai darbo ir gyvenimo pusiausvyrą sudaro daug ịvairių aspektų, veiksnių, kurie tą pusiausvyrą apibrěžia, suteikia jai konkrečią prasmę, ne visi veiksniai pasirodè reikšmingi vertinant pasitenkinimą darbu. Taigi visuminis darbinio ir šeiminio gyvenimo pusiausvyros vertinimas nesudaro pagrindo teikti rekomendacijas, kaip tobulinti socialinę politiką, tam būtina ịtraukti paskirus darbinio ir šeiminio gyvenimo pusiausvyros komponentus. Rengiant empirinius tyrimus šioje srityje svarbu sukurti kuo išsamesnį darbinio ir šeiminio gyvenimo pusiausvyros veiksnių modelį, nes ribotas, neišsamus veiksnių sąrašas gali duoti tik dalinį ar net iškreiptą vaizdą apie darbinio ir šeiminio gyvenimo pusiausvyrą organizacijoje.

PAGRINDINIAI ŽODŽIAI: darbinio ir šeiminio gyvenimo pusiausvyra, pasitenkinimas darbu, socialinès globos paslaugos, Lietuva.
\end{abstract}

DOI: http://dx.doi.org/10.15181/tbb.v74i2.1363 


\section{Introduction}

No matter how important work or career may be in modern societies, time devoted to personal life, leisure and family life is also a highly relevant indicator of quality of life. The question of work-life balance (WLB) is relevant not only for employees with family responsibilities (caring for children, elderly or disabled adults), but also for any other employee. It is therefore not surprising that WLB, although acquiring various configurations and aspects, has been the focus of scholarly literature for a number of decades. The WLB topic has been attracting attention mainly due to the increase in the employment of women, particularly mothers (Crompton, Lyonette, 2006). If until the 1980s the question of WLB in Europe was relevant primarily due to the rapid labour market integration of women and gender equality problems, later the WLB issues appeared in the analyses of quality of life, workplace, occupational well-being or well-being of persons in general. The range of WLB research is very broad, from general issues of WLB discourse and its origin (Lewis et al., 2007; Rantanen et al., 2011), WLB peculiarities between women and men (Crompton and Lyonette, 2006; Emslie and Hunt, 2009), influence of WLB on success of organisation's activities (Bloom and Reenen, 2006; Beauregard et. al., 2009; Gulbahar et al., 2014) up to explorations into links between WLB and job and/or life satisfaction, psychological well-being of individuals (Rantanen et al., 2011; Mukururi and Ngari, 2014; Haar et al., 2014), etc.

The aim of the article is to reveal work-life balance as a factor of job satisfaction in social care services in Lithuania. The social care sector is often characterised by high rates of turnover and absenteeism, high rates of burnout and overwhelming workload. This leads to low levels of JS and quality of life among employees. Studies based upon surveys in different countries reveal that one of important factors of JS is WLB. After the Restoration of Independence in 1990, in order to get rid of the Soviet Union heritage of mandatory overall employment, Lithuania rushed to the other extreme in order to return women to the family. Therefore, despite the fact that the new family support legislation emphasised family-work balance, extension of parental leave and enlargement of the benefits were maximised, the issues of flexible employment or work conditions friendly to family life were underestimated. Nowadays, public policy discourse in the EU and also in Lithuania reveals the growing attention to the issue of WLB, especially in the context of ageing society, development of the long-term care sector or implementation of EU employment strategy (Working and caring: Reconciliation measures in times of demographic change, 2015; Adequate social protection for long-term care needs in an ageing society, 2014; European employment strategy, 2014). On the other hand, WLB as a factor of JS remained in periphery of the inter- 
est of social policy and research in Lithuania. In this context, the social care sector appears to have attracted the least research. This sector is interesting also due to the fact that in Lithuania personal social services, as a separate area of welfare, as well as the profession of social work were established only after 1990. Society ageing, changing family structure, emigration, etc. lead to the growing need for employees in the social care sector. However, unattractive working conditions in the sector make it difficult to retain workers and attract new ones. Research studies in other countries show that the unattractiveness of working conditions in the social care sector is determined by heavy workloads, high levels of burnout or psychological distress, low pay, poor career advancement opportunities, etc. (Whitaker et al., 2006; Kim and Stoner, 2008; Arrington, 2008; Coffey et al., 2009). In this respect, the Lithuanian social care sector is not an exception. A questionnaire survey of social workers carried out in 2008 revealed that more than 36 per cent of respondents experienced stress at work at least once a week. In addition to low pay, main reasons for stress at work included burnout due to heavy workloads, infrequent rest, lack of vacation (Lazutka et al., 2008). The circumstances above undoubtedly influence WLB opportunities for employees and concurrently have effects on their JS. In view of these multinational findings suggesting that WLB is an important indicator for JS, this article employs empirical research data to answer the question of whether the same is true for the Lithuanian social care sector and what individual WLB components influence JS. The practical relevance of such research can be also linked with the relationship between JS and quality of services.

\section{Theoretical and methodological premises for work-life balance analyses as a factor of job satisfaction}

Despite the popularity of the WLB analysis in the academic society, there is a variety of concepts of WLB and no single definition for this phenomenon. Manfredi and Holliday (2004) argue that the concept of WLB is based on the notion that paid work and personal life should be seen less as competing priorities than as complementary elements of a full life. According to Clarke et al. (2004), the concept of WLB is generally associated with equilibrium or maintaining an overall sense of harmony in life. Lazăr et al. (2010) point out that WLB should not be seen as devoting equal amounts of time to paid work and non-paid roles; in its broader sense, it should be associated with a satisfactory level of involvement or "fit" between the multiple roles in a person's life. Trying to define the concept of WLB, Rantanen et al. (2011) distinguish between two approaches to the phenomenon: overall appraisal approach and components approach. The overall appraisal refers to an individual's general assessment concerning the entirety of his or her life 
situation. For example, WLB has been defined as "satisfaction and good functioning at work and home, with a minimum of role conflict" (Rantanen et al., 2011, p. 29). The components approachto WLB emphasises balance as a direct formative latent construct, which means that work-family balance consists of multiple facets that precede balance and give meaning to it. For example, according to Greenhaus et al. (2003), WLB consists of time balance, involvement balance, and satisfaction balance. According to Frone (2003), in turn, work-family balance consists of work-family conflict and work-family facilitation (corresponding with role conflict and enhancement, respectively).

Like in case of WLB, there is a lack of consensus over the meaning of JS in literature. Ravari et al. (2012) divided the concepts of JS into six groups based on a systematic review study, namely: 1. JS as an affect: an individual's emotional reaction to important facets of work. 2. JS as an attitude: a positive or negative evaluative judgment one makes about one's job or job situation. 3. JS as an expectation: the difference between the amount of rewards workers receive and the amount they believe they should receive. 4. JS as a belief system: job satisfaction decreases when intrinsic work values are not met. 5. JS as a multidimensional construct: it is admitted that job satisfaction is a complex multidimensional concept and there is no consensus model for the dimensions of job satisfaction. 6. JS as adependent concept: various features of the job environment are causes of JB. In accordance with the latter concept, WLB can be considered one of the factors determining JS.

Haar et al. (2014) research conducted in different countries of the world revealed a strong positive relationship between WLB and JS, and that implementation of WLB practices is a key driver of employees' job satisfaction. Among other things, the latter relationship was found to be stronger in countries with individualistic culture than those with prevailing collectivistic cultures. Research shows that age and gender dimensions also influence the relationship between WLB and JS.

The above discussed theoretical premises serve as a basis for defining a theoretical framework where JS is considered a dependent concept, WLB - one of JS factors; in turn, WLB is defined as a multidimensional construct which can be analysed on the basis of overall appraisal approach and components approach. When the overall appraisal approach is applied, WLB is associated with the subjective general assessment of the WLB situation by an individual, without going into a detailed analysis of different aspects of WLB. The component approach, in turn, means that WLB consists of various particular factors influencing this balance (Figure 1). 


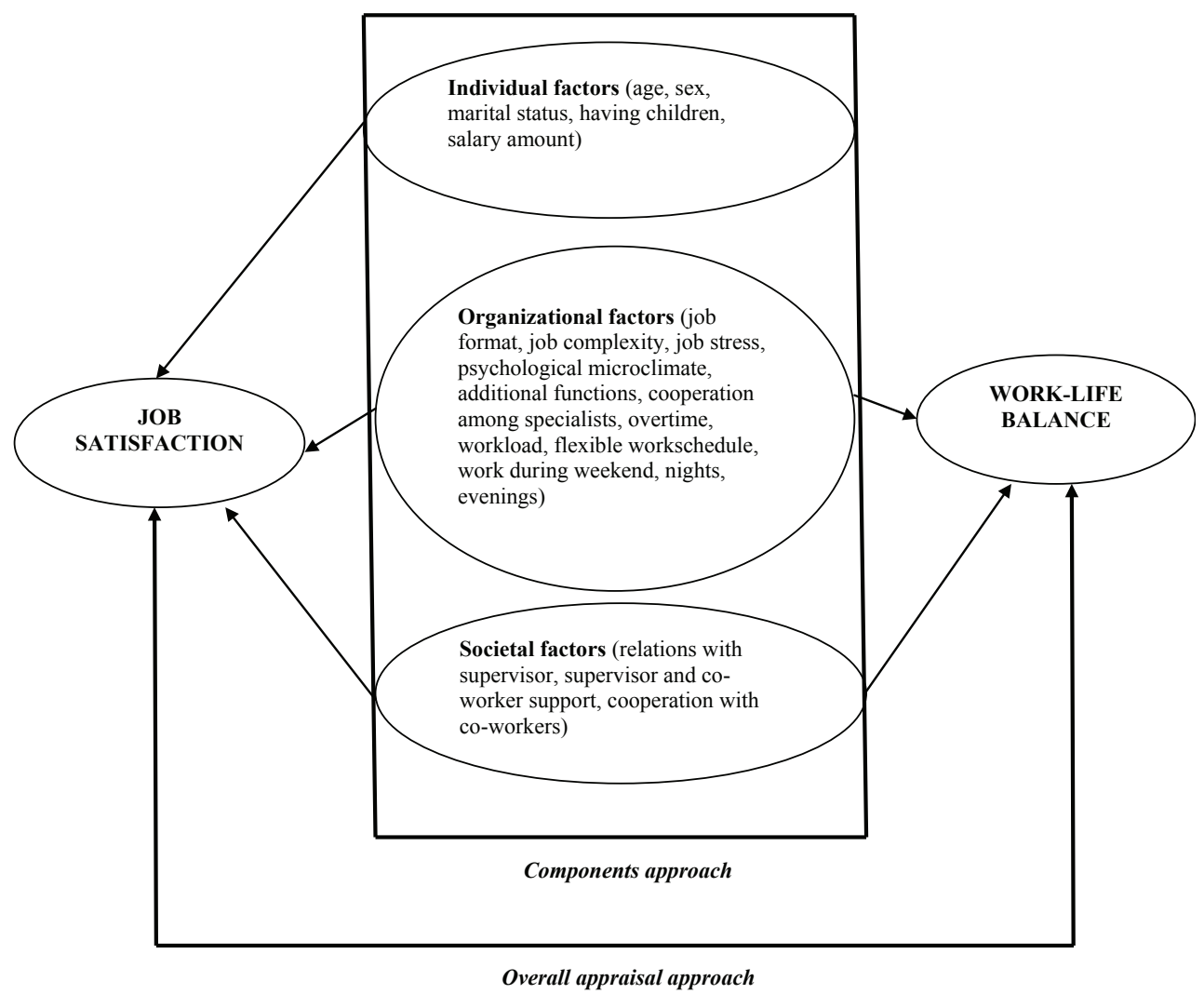

Fig. 1. Conceptual framework of work-life balance in job satisfaction research

\section{Empirical research data and methods of data collection}

The article uses empirical research data obtained through the implementation of the project "Occupational well-being of employees in the area of social work in Lithuania" (contract No. SIN-02/2011) funded by the Research Council of Lithuania. The methodology of the empirical research was based on quantitative research strategies. A questionnaire survey of employees engaged in social work was carried out in December 2011 - February 2012. It was a paper-based survey. Three-stage nested sampling design was applied. Firstly, it was selected 20 from 60 municipalities of Lithuania. Then 117 social services agencies were selected. Agencies were selected according to the type of social services agencies (child care home; elderly care home; day center etc.), to the place of agencies (city, village) and to the subordination of agencies (state; municipality; NGO). Finally, the selection according to three workers positions (social workers; social workers assistants, home helpers; heads of the organizations) was carried out. A total of 
789 questionnaires were received (accounting for approximately 5 per cent of general aggregate, considering that about 15.5 thousand people were employed in the area of social work in Lithuania in 2012) $)^{1}$. The data was analysed using Statistical Package for Social Sciences, SPSS Inc. (Version 17), descriptive statistical analysis and non-parametric statistics (Chi-squared test; Mann-Whitney U test for two independent samples; Kruskal-Wallis $\mathrm{H}$ test for $k$-independent samples). Correlation between variables was measured using the Cramer's V measure of association.

\section{Results}

\subsection{Overall evaluation of work-life balance and job satisfaction}

As mentioned, the overall appraisal approach means individual's general assessment of the work-life situation. In the research at issue, empirical indicators were evaluations of JS and WLB measured using a five-point scale ${ }^{2}$. According to the findings, respondents satisfied with their job accounted for 68.2 per cent and those not satisfied - for 31.8 per cent. However, only 55.7 per cent of the respondents were found satisfied with WLB and comparatively more respondents, 44.3 per cent, were dissatisfied with it. It can be presumed that WLB as a factor of JS is not important for all respondents. On the other hand, the findings suggest that these two variables are statistically significantly interdependent $(p=0.000<0.05$; Cramer's coefficient of association (V) is equal to 0.274$)$, because those agreeing with the statement that there are favourable conditions for WLB created in their workplace appear to be more frequently satisfied with their job than those disagreeing with the aforementioned statement (80.2 per cent and 54.6per cent, respectively).

To sum up, general evaluations of JS and WLB are related and WLB can be considered as a factor of JS.

As mentioned above with reference to WLB conceptualisation, factors forming WLB can be grouped into individual factors, organisational factors and societal factors (see Table 1). The analyses of these groups of factors is provided below.

1 Data of the Lithuanian Ministry of Social Security and Labour.

2 For the purpose of statistical analysis, due to the lack of frequency of the first two and the last values, the variable "job satisfaction" was modified by replacing five variable values (on the scale of 1 (very dissatisfied) to 5 (very satisfied) with two variable values (where 1 stands for satisfied or very satisfied employees and 0 stands for very dissatisfied, dissatisfied or neutral employees). 
3.2. Individual factors of job satisfaction and work-life balance

Age is one of the individual factors. Age is considered to be an important factor in subjective evaluations, as individuals have subjective norms concerning various concepts depending on their own situation (Van Praag and Frijters, 1999). Age can be one of the situational factors determining greater experience of an individual, peculiarities of individual's needs, etc. and, in turn, influencing individual's evaluations. Findings of this research revealed a statistically significant difference in the evaluations of respondents representing different age groups, i.e. employees above 45 report higher JS than those under 45. Some foreign research studies emphasise the influence of age on WLB, too. For example, findings of a public service employee survey carried out in Canada showed that employees aged 24 years or younger tended to report higher levels of support for WLB than did their older counterparts (Focus on Work-Life Balance and Workload, 2015). According to Yeandle (2005), WLB is relevant not only at younger ages when families are parenting young children, but in older ages, too. According to the author, the 50+ group also encounters work-life tensions which sources include caring for frail elderly relatives or a spouse, a desire to spend more time with grandchildren. In addition, older people themselves suffer various health problems and therefore tend to have lighter workloads, less stressful jobs requiring less overtime or weekend work, etc. According to the findings of this research, age has no influence on the evaluation of WLB in the Lithuanian social care sector, i.e. WLB opportunities are equally seen by both younger and older employees.

The question of WLB is extremely relevant for women who account for the absolute majority in the social care sector. Basing on the analysis conducted by Crompton and Lyonette (2006) for five European countries (Great Britain, Finland, France, Norway and Portugal), there are higher levels of work-life conflict among women than among men. This conclusion is based on the argument that women still undertake a greater share of caring and domestic work. However, the majority of both male and female respondents in social work in Lithuania had similar opinions about the presence of favourable conditions for WLB in their workplaces; there is no statistically significant difference between male and female evaluations in respect of this statement. Likewise, no statistically significant difference was found between male and female evaluations of JS. Accordingly, our analysis suggests that the respondents' gender has influence neither on the evaluations of organisational support for WLB nor on the evaluations of JS.

Based on this analysis, it can be further concluded that there is no statistically significant difference in the evaluations of JS among respondents with different marital status (married, unmarried, widowed, divorced). Also, respondents with 
children under 18 years old living together and those having no children were found to have the same opinion about JS. Marital status and having/not having children have no statistically significant influence on the evaluation of WLB, either. Similarly, findings of a research conducted in Romania in 2013 also showed that marital status had no influence on the respondents' evaluation of WLB. Unmarried, married without children, married with children under 18, married with children over 18 did not have a significantly different level of WLB (Panisoara and Serban, 2013).

Barnett et al. (2003) found a relationship between employees' income and maintaining WLB: lower-income employees, especially single mothers, face greater challenges in trying to balance their work demands and family responsibilities. A survey carried out in the UK has shown that employees more satisfied with pay are more likely to be satisfied with their job in general (Hooker et al., 2011). Similar trends have been observed in the Lithuanian social service sector: respondents seeing their pay as low, medium and high have different levels of JS. The absolute majority of employees ( 90 per cent) seeing their pay as high said they are satisfied with their job. JS between employees seeing they pay as medium and those who perceived their pay as low accounted for 79.7 per cent and 62.5 per cent, respectively. The analysis of WLB evaluations among employees differently perceiving their pay in terms of size showed that the majority of satisfied employees (62.6 per cent) in this context were those reporting medium pay. Employees seeing their pay as low or high reported similar levels of WLB satisfaction, 52.8 per cent and 50.0 per cent, respectively. One of possible explanations for such a distribution of evaluations in the Lithuanian social service sector is that higher paid employees have heavier workloads and more responsibilities. As a result, they have less time for personal life and fewer opportunities to achieve WLB.

The summary and comparison of the influence of individual factors on the evaluations of JS and WLB in the social care sector suggest that there is a relationship between these evaluations and perceived size of pay, but no relationship was found between JS/WLB and gender, marital status and having children under 18 living together. It was also observed that, in addition to the size of pay, levels of JS also depend on age which was found irrelevant for the evaluation of WLB. 
WORK-LIFE BALANCE (WLB) AS A FACTOR OF JOB SATISFACTION (JS) IN...

Table 1. Individual factors: job satisfaction and work-life balance

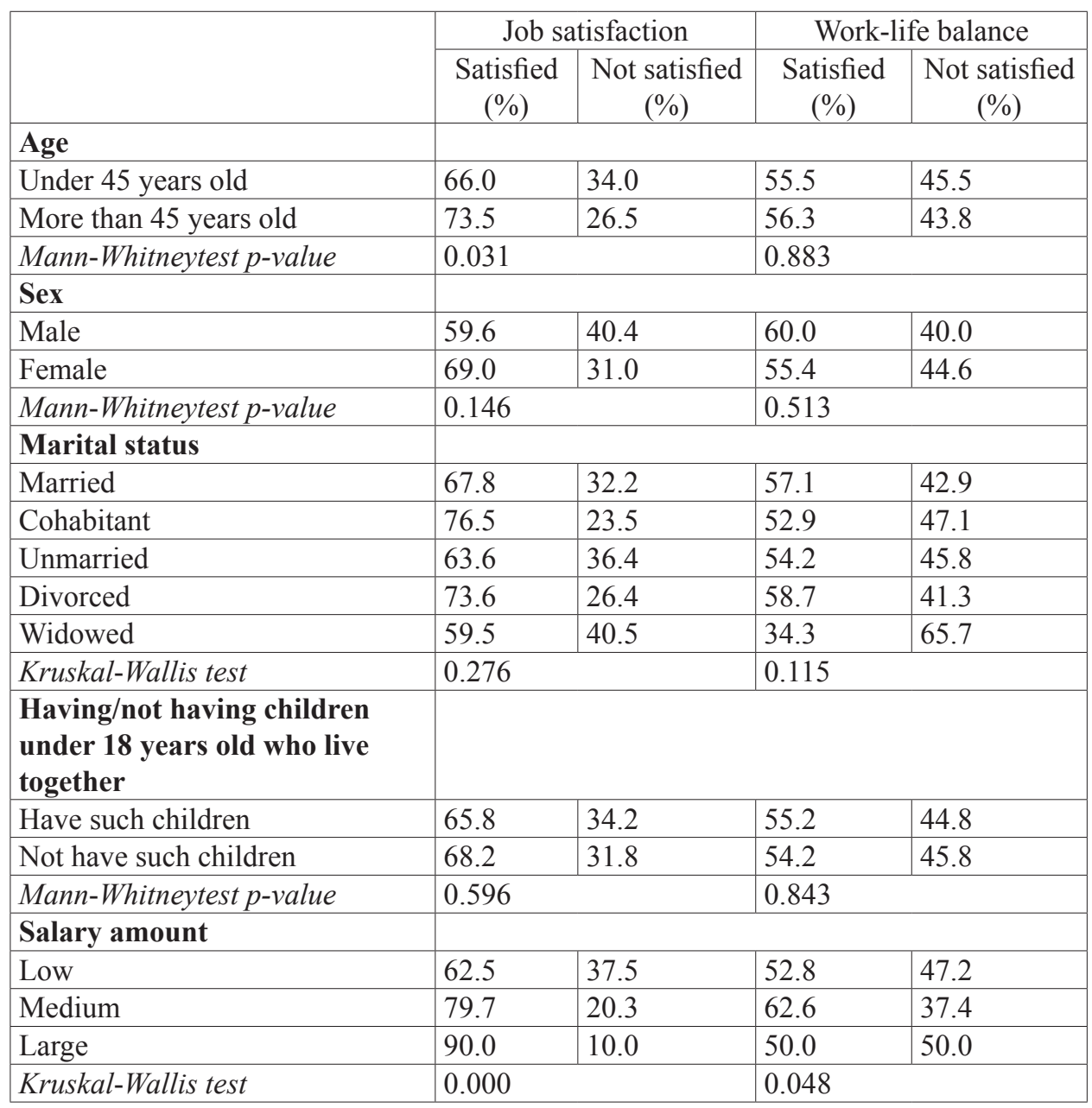

3.3. Organisational factors of job satisfaction and work-life balance

In the context of WLB assessments, researchers analyse not only individual factors, but organisational ones as well. The list of the latter factors can be very diverse, but the authors of the present research concentrated on such factors as workloads, psychological microclimate, job format, cooperation among specialists, etc. (see Table 2). According to research findings provided by foreign authors (e.g. Mayo et al., 2008, Boxall and Macky, 2014), long working hours are associated with greater work-life imbalance, whilst the need to work overtime positively correlates with work-life conflict exacerbation. Hooker et al. (2011) found that employees see flexible working arrangements as an opportunity to have more free 
time and to spend more time with their family. According to the aforementioned survey conducted in the UK, employees more satisfied with their working arrangements are more likely to be satisfied with their job in general (Hooker et al., 2011). According to the findings of the 2014 public service employee survey carried out in Canada, employees who worked according to flexible working arrangements reported greater organisational support for WLB (Focus on Work-Life Balance and Workload, 2015). A survey carried out in Canada in 2002 demonstrated that employees who face difficulties in balancing work-life are more likely to be under stress at work: 55 percent of employees who found it harder to balance work-life reported often or always being under stress in their job, compared with 26 percent of those who found WLB easier to achieve (Lowe, 2006).

The research findings in Lithuania also confirm that evaluation of various organisational factors influences the evaluations of JS and WLB. One of them is job format (varying or routine). Respondents perceiving their job as varying more often reported being satisfied with their present job than those who saw their job as routine or neither varying nor routine. Similarly, respondents perceiving their job as varying more often reported being satisfied with their WLB than those who saw their job as routine or neither varying nor routine.

On the other hand, the research revealed that job complexity is irrelevant for the evaluation of JS and WLB. However, it is noteworthy that the majority of employees engaged in social work (approx. 80 per cent) reported complexity of their job and this could render this variable irrelevant.

Work in the social care sector is often associated with high emotional tensions, risks of burnout, etc. It was therefore interesting to explore how job-related stress acts on JS and WLB of sector's employees. The statistical analysis revealed that job-related stress is statistically significantly related to the evaluation of both JS and of WLB. Representatives of social work being under stress at work more often tend to be less satisfied with their job and WLB. For example, 55.9 per cent of employees who reported being under stress at work more than once a week said they were satisfied with their job, compared with 79.7 per cent of those who felt stress very rarely/never.

JS and WLB are influenced not only by stress, but also by the psychological microclimate at work. Employees evaluating organisational microclimate as good were more likely to be satisfied with their job and WLB, compared with those perceiving the microclimate as bad or neutral. For example, 77.6 per cent of employees who evaluated the organisational microclimate as good were satisfied with the job, compared with 41.2 per cent of those who saw the microclimate as bad.

The psychological microclimate at work is closely associated with another organisational factor, cooperation among specialists in addressing customer's prob- 
lems. Employees who reported sufficient level of cooperation among specialists in their organisation tended to be more often satisfied with their present job than those reporting insufficient cooperation. Similarly, respondents reporting sufficient level of cooperation among specialists in their organisation were more often satisfied with their WLB.

Workloads and tensions are also reflected by such an empirical variable as additional functions not specified in job description. This indicator is particularly relevant in the Lithuania's social care sector which is rather new and lacking well-established job functions, their clear distribution and specification in job descriptions. It was found out that the frequency of performing additional functions influences the evaluations of JS and of WLB. Employees very rarely or never performing additional functions were more often satisfied with their job than those who cannot avoid additional functions. For example, employees who perform additional functions very rarely or never represented $77.4 \mathrm{p}$ er cent of those satisfied with their job, as compared with 65.3per cent of employees frequently performing additional functions and satisfied with their job. 67.4 per cent of employees performing additional functions very rarely / never were satisfied about their WLB, compared with only 49.6 per cent of employees satisfied with their WLB among those who have to perform additional functions frequently.

Further analysis of the influence of organisational factors on JS and WLB shows, in both cases, no significant relationship between the respondents' evaluations and frequency of work during weekends, overtime frequency during work days / after work, and workloads. Likewise, work during weekends, events or nights have no influence on the evaluation of WLB (see Table 2). Such evaluations are probably related to the specificality of work in the social care sector (e.g. employees in children homes or homes for the elderly work rotating shifts and get used to such a rhythm of work).

Flexible work arrangement is often identified as one of the most important aspects of WLB. According to our survey data, there is a correlation between the use of flexible work arrangements and evaluation of WLB $(p=0.000<0.05$; Cramer's coefficient of association (V) is equal to 0.478). Respondents considering their work conditions as favourable for flexible arrangements more often report favourable conditions for WLB, compared to those who cannot use flexible work arrangements. In turn, there is a statistically significant difference in levels of JS between those who can use flexible work arrangements and those who cannot. 
Laimute Žalimienè, Jolita Junevičienė

Table 2. Organisational factors: job satisfaction and work-life balance

\begin{tabular}{|c|c|c|c|c|}
\hline & \multicolumn{2}{|c|}{ Job satisfaction } & \multicolumn{2}{|c|}{ Work-life balance } \\
\hline & $\begin{array}{c}\text { Satisfied } \\
(\%)\end{array}$ & $\begin{array}{c}\text { Not satisfied } \\
(\%)\end{array}$ & $\begin{array}{c}\text { Satisfied } \\
(\%)\end{array}$ & $\begin{array}{c}\text { Not satisfied } \\
(\%)\end{array}$ \\
\hline \multicolumn{5}{|l|}{ Job format } \\
\hline Routine & 38.9 & 61.1 & 49.1 & 50.9 \\
\hline Nor routine, nor varying & 64.5 & 35.5 & 37.6 & 62.4 \\
\hline Varying & 71.3 & 28.7 & 58.9 & 41.1 \\
\hline Kruskal-Wallis test & \multicolumn{2}{|l|}{0.000} & \multicolumn{2}{|l|}{0.000} \\
\hline \multicolumn{5}{|l|}{ Job complexity } \\
\hline Simple & 76.5 & 23.5 & 76.5 & 23.5 \\
\hline Nor complicated, nor simple & 69.0 & 31.0 & 54.9 & 45.1 \\
\hline Complicated & 67.7 & 32.3 & 55.2 & 44.8 \\
\hline Kruskal-Wallis test & \multicolumn{2}{|l|}{0.723} & \multicolumn{2}{|l|}{0.215} \\
\hline \multicolumn{5}{|l|}{ Job stress } \\
\hline Very rarely / never & 79.7 & 20.3 & 73.8 & 26.2 \\
\hline Once every three months & 67.9 & 32.1 & 66.0 & 34.0 \\
\hline Once a month & 74.8 & 25.2 & 57.4 & 42.6 \\
\hline Once a week & 67.1 & 32.9 & 53.8 & 46.2 \\
\hline More than once a week & 55.9 & 44.1 & 42.2 & 57.8 \\
\hline Kruskal-Wallis test & \multicolumn{2}{|l|}{0.000} & \multicolumn{2}{|l|}{0.000} \\
\hline \multicolumn{5}{|l|}{ Psychological microclimate } \\
\hline Bad & 41.2 & 58.8 & 36.4 & 63.6 \\
\hline Nor bad, nor good & 54.0 & 46.0 & 41.3 & 58.7 \\
\hline Good & 77.6 & 22.4 & 64.2 & 35.8 \\
\hline Kruskal-Wallis test & \multicolumn{2}{|l|}{0.000} & \multicolumn{2}{|l|}{0.000} \\
\hline \multicolumn{5}{|l|}{ Additional functions } \\
\hline Very rarely / never & 77.4 & 22.6 & 67.4 & 32.6 \\
\hline Rarely & 64.1 & 35.9 & 50.9 & 49.1 \\
\hline Often & 65.3 & 34.7 & 49.6 & 50.4 \\
\hline Kruskal-Wallis test & \multicolumn{2}{|l|}{0.004} & \multicolumn{2}{|l|}{0.000} \\
\hline \multicolumn{5}{|l|}{ Cooperation among specialists } \\
\hline Insufficient & 57.1 & 42.9 & 45.1 & 54.9 \\
\hline Nor sufficient, nor insufficient & 49.0 & 51.0 & 41.1 & 58.9 \\
\hline Sufficient & 74.9 & 25.1 & 60.9 & 39.1 \\
\hline Kruskal-Wallis test & \multicolumn{2}{|l|}{0.000} & \multicolumn{2}{|l|}{0.000} \\
\hline \multicolumn{5}{|c|}{\begin{tabular}{|l|l} 
Overtime frequency during weekend & \\
\end{tabular}} \\
\hline Very rarely / never & 67.3 & 31.7 & 56.8 & 43.2 \\
\hline Rarely & 62.0 & 38.0 & 55.0 & 45.0 \\
\hline Often & 73.7 & 26.3 & 52.1 & 47.9 \\
\hline Kruskal-Wallis test & \multicolumn{2}{|l|}{0.254} & \multicolumn{2}{|l|}{0.684} \\
\hline $\begin{array}{l}\text { Overtime frequency during } \\
\text { days, after work }\end{array}$ & & & & \\
\hline
\end{tabular}


WORK-LIFE BALANCE (WLB) AS A FACTOR OF JOB SATISFACTION (JS) IN...

\begin{tabular}{|c|c|c|c|c|}
\hline & \multicolumn{2}{|c|}{ Job satisfaction } & \multicolumn{2}{|c|}{ Work-life balance } \\
\hline & $\begin{array}{c}\text { Satisfied } \\
(\%)\end{array}$ & $\begin{array}{c}\text { Not satisfied } \\
(\%)\end{array}$ & $\begin{array}{c}\text { Satisfied } \\
(\%)\end{array}$ & $\begin{array}{c}\text { Not satisfied } \\
(\%)\end{array}$ \\
\hline Very rarely / never & 69.4 & 30.6 & 57.7 & 42.3 \\
\hline Rarely & 64.3 & 35.7 & 54.9 & 45.1 \\
\hline Often & 69.5 & 30.5 & 48.8 & 51.2 \\
\hline Kruskal-Wallis test & \multicolumn{2}{|l|}{0.507} & \multicolumn{2}{|l|}{0.212} \\
\hline \multicolumn{5}{|l|}{ Work load } \\
\hline Little & 66.7 & 33.3 & 58.3 & 41.7 \\
\hline Optimal & 71.8 & 28.2 & 59.8 & 40.2 \\
\hline Large & 65.0 & 35.0 & 51.3 & 48.7 \\
\hline Kruskal-Wallis test & \multicolumn{2}{|l|}{0.136} & \multicolumn{2}{|l|}{0.067} \\
\hline \multicolumn{5}{|l|}{ Flexible work schedule } \\
\hline Yes & 76.8 & 23.2 & 80.0 & 20.0 \\
\hline No & 62.5 & 37.5 & 33.2 & 66.8 \\
\hline Don't know & 57.3 & 42.7 & 30.4 & 69.6 \\
\hline Kruskal-Wallis test & \multicolumn{2}{|l|}{0.000} & \multicolumn{2}{|l|}{0.000} \\
\hline \multicolumn{5}{|l|}{ Work during weekend } \\
\hline Yes & 68.6 & 31.4 & 56.6 & 43.4 \\
\hline No & 68.7 & 31.3 & 55.3 & 44.7 \\
\hline Mann-Whitneytest p-value & \multicolumn{2}{|l|}{0.975} & \multicolumn{2}{|l|}{0.717} \\
\hline \multicolumn{5}{|c|}{ Work during nights, evenings } \\
\hline Yes & 66.2 & 33.8 & 54.6 & 45.4 \\
\hline No & 69.1 & 30.9 & 56.0 & 44.0 \\
\hline Mann-Whitneytest p-value & \multicolumn{2}{|l|}{0.409} & \multicolumn{2}{|l|}{0.724} \\
\hline
\end{tabular}

To sum up the influence of organisational factors on the evaluations of JS and WLB, it can be concluded that these evaluations are dependent on job format, job stress, psychological microclimate, performance of additional functions, cooperation among specialists and opportunities for flexible work arrangements. No statistically significant influence was found between the evaluations above and job complexity, overtime frequency during weekends, workdays or after work, workloads and work during weekends, nights or evenings.

3.4. Societal factors of job satisfaction and work-life balance

WLB is also associated with supportive work environment, support from coworkers, supervisors etc. This supportiveness of environment can be measured by different indicators. For instance, findings of our research suggest (see Table 3) that there is a statistically significant difference in levels of JS reported by employees agreeing and disagreeing with the statement "In our organisation, the relationships between employees and supervisors are based on mutual respect and dignity". A 
considerably bigger percentage of those agreeing with the mentioned statement were satisfied with their job, compared to those who disagreed with this statement (75.5 per cent vs. 56.5 per cent). Similarly, there was a statistically significant correlation found between the evaluations of the statement above and WLB: 62.1 per cent of the respondents agreeing with the statement that the relationships between employees and supervisors in their organisation are based on mutual respect and dignity were satisfied with their WLB, compared to 37.0 per cent of the respondents disagreeing with this statement.

It was found out that levels of satisfaction with WLB among employees of the social service sector depend not only on the respect-based relationship between employees and superiors, but also on support from co-workers and supervisors in case of any problems at work. The analysis of statements "I always receive support from my superior in case of problems at work" and "I always receive support from my co-workers in case of problems at work" in both cases revealed statistically significant differences. 73.0 per cent and 60.0 per cent of those feeling support from their peers or supervisors in case of problems at work were satisfied with their job and WLB, respectively, as compared to almost half of those satisfied with their job and WLB among the respondents who don't feel support from their peers or supervisors at work.

Some differences have been also observed with regard to support from coworkers and supervisors in case of personal problems. There is a statistically significant influence of support from supervisors in case of personal problems on JS, but no influence of support from co-workers.

Support from co-workers and supervisors in case of personal problems was found to be equally influential to the evaluation of WLB $(p=0.000<0.05$ in both cases), i.e. those who receive support from their supervisors and co-workers in case of personal problems are considerably more likely to be positive about their WLB.

In the context of societal factors, cooperation with co-workers should be singled out as one of the key principles for efficient social work. Statistically significant differences in the evaluation of JS and WLB have been found between employees agreeing with the statement "In our organisation, there is efficient cooperation between social workers and social work assistants in provision of social services" and those disagreeing with this statement. 72.2 per cent of the employees who agree with the statement are satisfied with the job, compared to 65.0 per cent of those who don't agree with the above statement. In turn, 61.1 per cent of the respondents agreeing with the statement are satisfied about their WLB vs. 43.3 per cent of those disagreeing with it. 
WORK-LIFE BALANCE (WLB) AS A FACTOR OF JOB SATISFACTION (JS) IN...

Table 3. Societal factors: job satisfaction and work-life balance

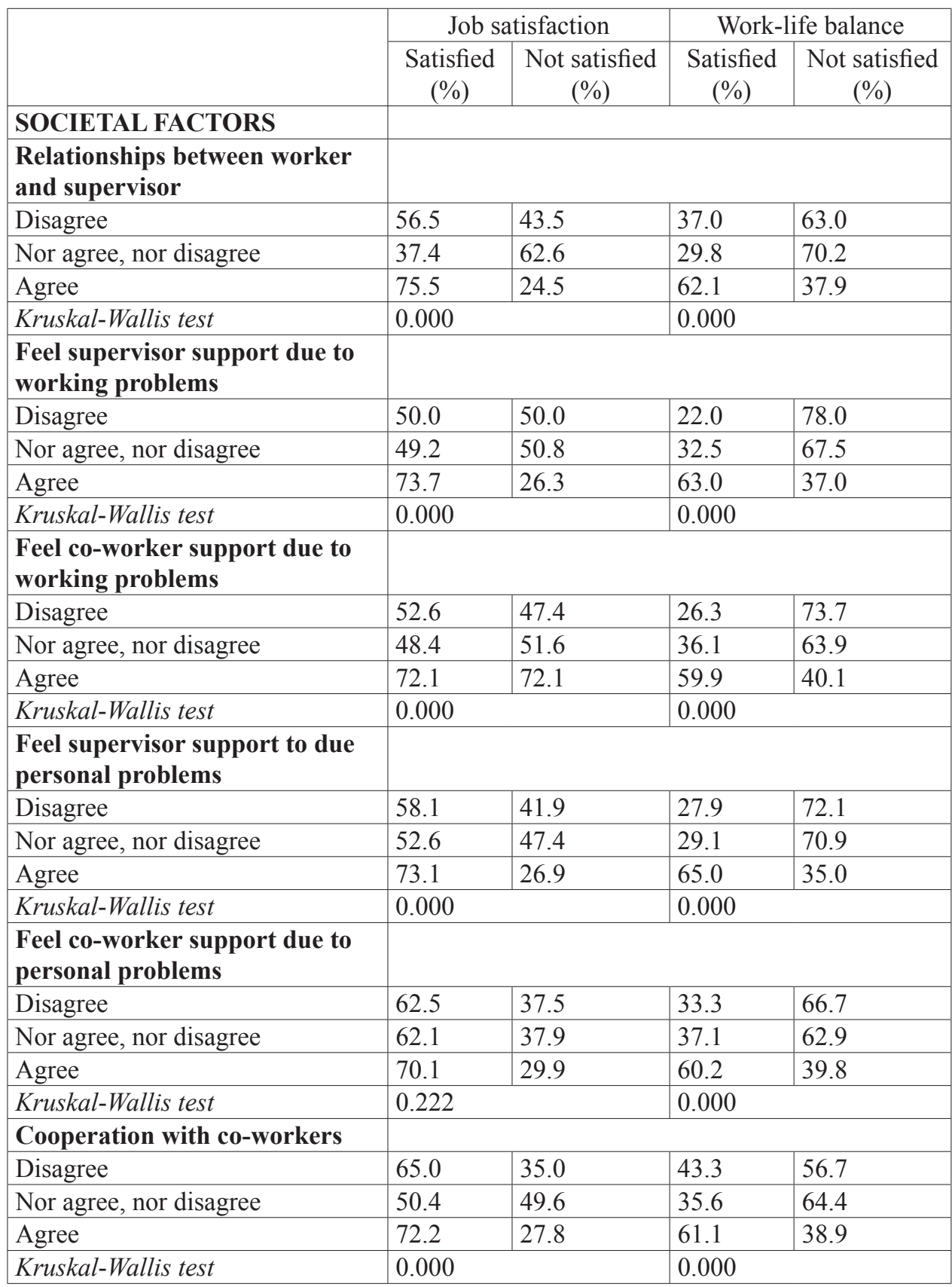


To sum up the influence of societal factors on the evaluations of JS and of WLB in the social service sector, these evaluations have been found to be influenced by the respectful relationships between supervisors and employees, support from supervisor and co-workers in case of working problems, support from supervisor in case of personal problems, and cooperation with co-workers. There was one difference observed in the evaluations of JS and WLB: support from coworkers in case of personal problems had no influence on the levels of JS, but was influential to the evaluation of WLB.

\subsection{Conclusions and implications for research and practice}

The research findings show that, based on the overall approach, WLB is an important factor of JS in social care services in Lithuania. In other words, employees satisfied with WLB in their organisation are more likely to be satisfied with their job in general. This is important given the growing need for labour in the social care sector as a result of society's ageing, changes in the family structure, migration processes, etc. In order to improve JS, i.e. to attract more young people, to retain older employees in this sector or to reduce employee turnover in organisations, it is important to pay sufficient attention to maintaining WLB.

In case of the components approach to WLB, whereby work-family balance is defined as consisting of multiple facets that precede balance and give specific meaning to it, not all WLB factors chosen for the research proved to be significant both for overall assessment of work-family balance and for JS. These figures (see Figure 2) can be classified into four groups: (a) factors relevant to both overall WLB assessment and JS; (b) factors relevant to overall WLB assessment, but irrelevant to JS; (c) factors irrelevant to overall WLB assessment, but relevant to JS; and (d) factors relevant neither to WLB nor to JS. Therefore, it can be concluded that not all of the factors that could be logically considered important for WLB are influential to the overall assessment of WLB and JS in real life. Moreover, the format of empirical indicators of WLB as a construct may result in different assessment configurations for WLB.

It should be noted that, in JS research identifying WLB as a factor of JS, overall WLB assessment does not reveal specific empirical indicators that are important for or determine this assessment. Therefore, the overall assessment of WLB does not provide basis for recommendations to increase employee JS or improve social policy. This requires a components approach which would provide a realistic pattern of specific indicators acting on WLB. It is also very important for research to have a construct of WLB factors as detailed and systematic as possible, because inconsistent list of factors may produce different "pictures" of WLB. 


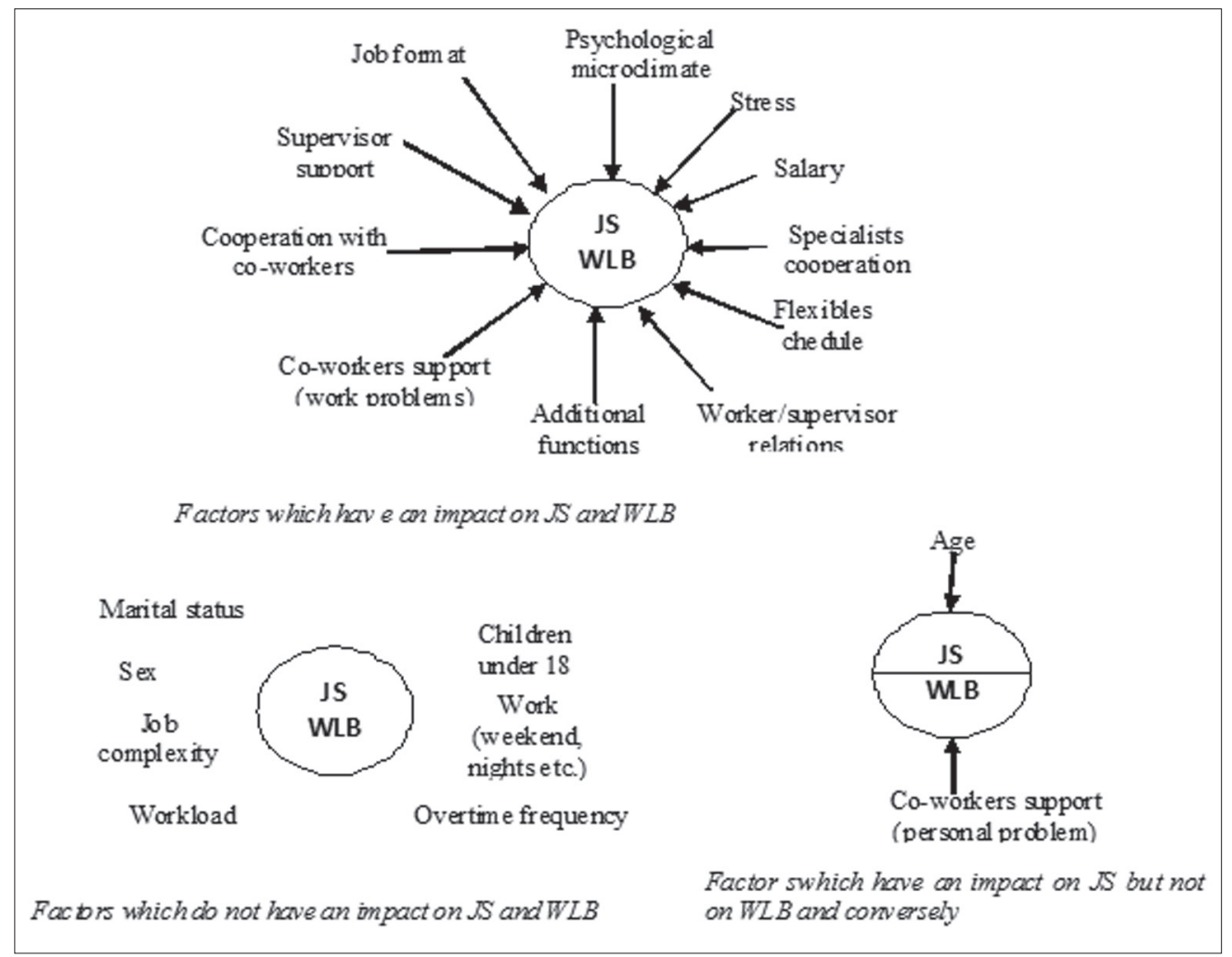

Fig. 2. Factor groups and factors of work-life balance by their importance for overall work-family balance and job satisfaction

Research limitations. It is necessary to keep in mind, that there was no special survey carried out for the problem analysis in this article. The analysis was based on empirical research findings obtained during the occupational well-being survey in the social care sector in Lithuania. This limited the selection of empirical indicators for the assessment of WLB and JS.

Received 20160704 Approved for publishing 20161015

\section{References}

Adequate social protection for long-term care needs in an ageing society. (2014). Social Protection Committee. http://ec.europa.eu/social/main.jsp?catId=738\&langId=en\&pubId=7724. Accessed: 02-25-2016.

Abendroth, A. K., Dulk, L. (2011). Support for the work-life balance in Europe: the impact of state, workplace and family support on work-life balance satisfaction. Work, employment and society, Vol. 25 (2), p. 234 256. DOI: $10.1177 / 0950017011398892$. 
Allen, T. D., Herst, D. E. L., Bruck, C. S., Sutton, M. (2000) Consequences Associated With Work-to-Family Conflict: A Review and Agenda for Future Research. Journal of Occupational Health Psychology, Vol. 5 (2), p. 278-308. DOI: 10.1037//1076-8998.5.2.278.

Arrington, P. (2008). Stress at work: How do social workers cope? NASW Membership Workforce Study. Washington, DC; National Association of Social Workers.

Barnett, K. A., Campo, R. L., Campo, D. S., Steiner, R. L. (2003). Work and Family Balance Among DualEarner Working-Class Mexican-Americans: Implications for Therapists. Contemporary Family Therapy, Vol. 25 (4), p. 353-366.

Beauregard, T. A., Henry, L. C. (2009). Making the Link Between Work-Life Balance Practices and Organizational Performance. Human Resource Management Review, Vol. 19, p. 9-22.

Behson, S. J. (2005). The relative contribution of formal and informal organizational work-family support. Journal of Vocational Behavior, Vol. 66 (3), p. 487-500. DOI: 10.1016/j.jvb.2004.02.004

Bloom, N., Reenen, J. (2006) Management Practices, Work-Life Balance, and Productivity: a Review of Some Resent Evidence. Oxford Review of Economic Policy, Vol. 22 (4), p. 1-26. DOI: 10.1093/oxrep/grj027

Bloom, N., Reenen, J. (2006). Management Practices, Work-Life Balance, and Productivity: a Review of Some Resent Evidence. Oxford Review of Economic Policy, Vol. 22 (4), p. 1-26.

Boxall, P., Macky, K. (2014). High-Involvement Work Processes, Work Intensification and Employee Well-Being. Work, Employment \& Society, Vol. 28 (6), p. 963-984.

Clarke, M. C., Koch, L. C., Hill, E. J. (2004). The Work-Family Interface: Differentiating Balance and Fit. Family and Consumer Sciences Research Journal, Vol. 33 (2), p. 121-140.

Coffey, M., Dugdill, L., Tattersall, A. (2009). Working in the Public Sector: A Case Study of Social Services. Journal of Social Work, Vol. 9 (4), p. 420-442.

Colombo, F., Llena-Nozal, A., Mercier, J., Tjadens, F. (2011).Help Wanted? Providing and Paying Long-Term Care. OECD Health Policy Studies, OECD Publishing. http://www.keepeek.com/Digital-Asset-Management/oecd/social-issues-migration-health/help-wanted_9789264097759-en\#page3. Accessed: 02-08-2016.

Crompton, R., Lyonette, C. (2006). Work-Life 'Balance' in Europe. ActaSociologica, Vol. 49 (4), p. $379-393$.

Emslie, C., Hunt, K. (2009). 'Live to Work' or 'Work to Live?' A Qualitative Study of Gender and Work-life Balance among Men and Women in Mid-life. Gender, Work and Organization, Vol. 16 (1), p. 151-172.

Focus on Work-Life Balance and Workload. (2015). Government of Canada. https://www.tbs-sct.gc.ca/psm-fpfm/ modernizing-modernisation/pses-saff/focus-regard-05-eng.asp. Accessed: 02-08-2016.

Frone, M. R. (2003). Work-Family Balance. In J. C. Quick, L. E. Tetrick (eds.). Handbook of Occupational Health Psychology. Washington, D. C.: American Psychological Association, p. 143-162.

Greenhaus, J. H., Collins, K. M., Shaw, J. D. (2003). The Relation Between Work-Family Balance and Quality of Life. Journal of Vocational Behavior, Vol. 63, p. 510-531.

Gulbahar, Amjad, A. Ch., Kundi, G. M., Qureshi, Q. A., Akhtar, R. (2014). Relationship between Work-Life Balance \& Organizational Commitment. Research on Humanities and Social Sciences, Vol. 4 (5), p. 1-7.

Haar, J. M., Russo, M., Sune, A., Ollier-Malaterre, A. (2014). Outcomes of Work-Life Balance on Job Satisfaction, Life Satisfaction and Mental Health: a Study Across Seven Cultures. Journal of Vocational Behavior, Vol. 85 (3), p. 361-373.

Hooker, H., Neathey, F., Casebourne, J., Munro, M. (2011). The Third Work-Life Balance Employee Survey: Main Findings. Employment Relations Research Series, Vol. 58, p. 1-249.

Kim, H., Stoner, M. (2008). Burnout and Turnover Intention Among Social Workers: Effectsof Role Stress, Job Autonomy and Social Support. Administration in Social Work, Vol. 32 (3), p. 5-25.

Lazăr, I., Osoian, C., Ratiu, P. (2010). The Role of Work-Life Balance in Order to Improve Organizational Performance. European Research Studies, Vol. 13 (1), p. 201-2014.

Lazutka, R., Skučienė, D., Žalimienė, L., Vareikytė, A., Kazakevičiutė, J. (2008). Socialinių darbuotojų profesinės rizikos veiksniai (Social Workers' Occupational Risks Factors). Socialinis darbas, Vol. 7 (3), p. 74-86.

Lewis, S., Gambles, R., Rapoport, R. (2007). The Constraints of a 'Work-Life Balance' Approach: an International Perspective. The International Journal of Human Resource Management, Vol. 18 (3), p. 360-373.

Lowe, G. (2006). Under Pressure: Implications of Work-Life Balance and Job Stress. Human Solutions Report, July.

Manfredi, S., Holliday, M. (2004). Work-Life Balance: An Audit of Staff experience at Oxford Brookes University. Wheatley Campus: Oxford Brooles University. 
Mayo, M., Pastor, J. C., Sanz, A. I. (2008). Enabling Managers to Achieve Work-Family Balance: a DemandsControl Model of Housework Behavior and Family Satisfaction. IE Business School Working Paper, WP08-20, p. 1-14.

On the Approval of the list of positions of social workers. Order No A1-401 of 4 December 2008 of the Minister for Social Security and Labour.

Panisoara, G., Serban, M. (2013). Marital Status and Work-Life Balance. Procedia-Social and Behavioral Sciences, Vol. 78, p. 21-25.

Poulose, S., Sudarsan, N. (2014). Work Life Balance: A Conceptual Review. International Journal of Advances in Management and Economics, Vol. 3 (2), p. 1-17.

Rantanen, J., Kinnunen, U., Mauno, S., Tillemann, K. (2011). Introducing Theoretical Approaches to Work-Life Balance and Testing a New Typology Among Professionals. In S. Kaiser, et al. (ed.). Creating Balance? Springer-Verlag Heidelberg, p. 27-46.

Ravari, A., Mirzaei, T., Kazaemi, M., Jamalizadeh, A. (2012). Job Satisfaction as a Multidimensional concept: A Systematic Review Study. JOHE, Vol. 1 (2), p. 95-102.

Tremblay, D. G., Genin, E., di Loreto, M. (2011) Advances and Ambivalences: Organisational Support to Worklife balance in a Police Service. Employment Relations Record, Vol. 11 (2), p. 75-93. http://search.informit. com.au/documentSummary;dn=273428462447837;res=IELBUS. Accessed: 31.05.2016.

Van Praag, B. M. S., Frijters, P. (1999). The measurement of welfare and wellbeing. Leyden Approach. http:// econrsss.anu.edu.au/ frijters/pdf/kahneman.pdf. Accessed: 02-08-2011.

Whitaker, T., Weismiller, T., Clark, E. J. (2006). Assuring the Suffiency of a Frontline Workforce: A National Study of Licensed Social Workers. Executive Summary. National Association of Social Workers.

Working and caring: Reconciliation measures in times of demographic change. (2015). Report. Eurofond. http:// www.eurofound.europa.eu/publications/report/2015/working-conditions-social-policies/working-and-caring-reconciliation-measures-in-times-of-demographic-change. Accessed: 02-08-2016.

Žalimienè, L., Skučienè, D., Junevičienėand, J., Gataūlinas, A. (2013). Profesinè gerové socialinio darbo paslaugu sektoriuje Lietuvoje (OccupationalWell-BeinginSocialWorkServicesin Lithuania). Vilnius: Lietuvos socialinių tyrimų centras. 
